\title{
High prevalence of noroviruses among hospitalized diarrheal patients in Bangladesh, 2011
}

\author{
Shamsun Nahar ${ }^{1}$, Mokibul Hassan Afrad ${ }^{2}$, Noorjahan Begum², Feroz Al-Mamun ${ }^{2}$, Azadul Kabir Sarker ${ }^{2}$, \\ Sumon Kumar Das ${ }^{2}$, Abu Syed Golam Faruque ${ }^{2}$, Mahmoud Reza Pourkarim ${ }^{3}$, Mohammad Sahabuddin \\ Kabir Choudhuri ${ }^{4}$, Tasnim Azim², Mustafizur Rahman ${ }^{2}$ \\ ${ }^{1}$ Department of Microbiology, Jahangirnagar University, Savar, Dhaka, Bangladesh \\ ${ }^{2}$ Virology Laboratory, icddr,b, Mohakhali, Dhaka-1212, Bangladesh \\ ${ }^{3}$ Laboratory of Clinical and Epidemiological Virology, Rega Institute for Medical Research, University of Leuven, \\ Leuven, Belgium \\ ${ }^{4}$ Department of Pharmacy, Jahangirnagar University, Savar, Dhaka, Bangladesh
}

\begin{abstract}
Introduction: Norovirus is not usually investigated in diarrheal patients in Bangladesh which may account for the many cases where no pathogens are identified.

Methodology: Stool specimens collected from diarrheal patients from three hospitals in Bangladesh during 2011 were investigated for norovirus RNA using real-time RT-PCR assay with norovirus type specific primers and probes.

Results: Of the 257 stool specimens tested, $28.4 \%$ were norovirus positive. GII (71.2\%) was the predominant strain followed by GI (20.5\%), GI+GII $(6.8 \%)$ and GIV (1.4\%). Half of the norovirus positive stools $(n=37)$ were co-infected with other pathogens.

Conclusion: Continued surveillance of norovirus together with other viral and bacterial pathogens in hospitalized gastroenteritis patients as well as in the community will further elucidate the role and burden of different pathogens in diarrheal diseases.
\end{abstract}

Key words: Norovirus; diarrhea; Bangladesh

J Infect Dev Ctries 2013; 7(11):892-896. doi:10.3855/jidc.2944

(Received 23 August 2012 - Accepted 09 December 2012)

Copyright (C) 2013 Nahar et al. This is an open-access article distributed under the Creative Commons Attribution License, which permits unrestricted use, distribution, and reproduction in any medium, provided the original work is properly cited.

\section{Introduction}

Norovirus (NoV) is an important cause of both acute and sporadic cases of viral gastroenteritis among persons of all ages globally. Recent reports from around the world indicate that NoV has become one of the most commonly identified pathogens and is responsible for the hospitalization for severe gastroenteritis of $12 \%$ of children less than 5 years of age (range 4.4-30.7\%) [1,2,3,4]. NoV is associated with nausea, vomiting, and diarrhea with abdominal cramps and is sometimes accompanied by malaise and low grade fever [5]. The disease is self-limiting; however, it can be severe in the elderly, very young or immune-compromised patients [5].

There is limited information about the role of NoV as an etiological agent for gastroenteritis among hospitalized patients in Bangladesh. During 1978-79, a serosurvey in rural Bangladesh indicated a high prevalence of NoV antibodies (43\%) in children less than 4 years of age [6]. Studies on molecular detection of NoV in urban hospitals indicated that $4.5 \%$ to $8.5 \%$ were hospitalized during 2004-05 due to NoV infection [7,8]. These studies relied on specific primers which could not detect all NoV types. In this study the presence of NoV RNA in stool specimens from diarrheal patients admitted to three geographically distant hospitals (one urban and two rural) in Bangladesh was investigated using real time PCR.

\section{Methodology}

Study population and sample selection

The International Centre for Diarrheal Disease Research, Bangladesh (icddr,b) runs etiology surveillance of diarrhea in one urban hospital situated in Dhaka and two rural hospitals in Matlab and Mirzapur. Stool specimens were obtained from diarrheal patients at three hospitals. After having verbal consents from the patients or their legal guardians, trained health workers registered and 
Table 1. Distribution of enteric pathogens in hospitalized diarrhea patients in Bangladesh, Jan-Dec 2011

\begin{tabular}{|c|c|c|c|c|}
\hline Pathogens & $\begin{array}{c}\text { Dhaka } \\
(\mathrm{n}=113)\end{array}$ & $\begin{array}{c}\text { Matlab } \\
(n=67)\end{array}$ & $\begin{array}{c}\text { Mirzapur } \\
(\mathrm{n}=77)\end{array}$ & $\begin{array}{c}\text { Total } \\
(\mathrm{n}=\mathbf{2 5 7})\end{array}$ \\
\hline Norovirus + rotavirus & $8(7.1 \%)$ & $2(3.0 \%)$ & $8(10.4 \%)$ & $18(7.0 \%)$ \\
\hline Norovirus + Campylobacter spp. & $2(1.8 \%)$ & - & - & $2(0.7 \%)$ \\
\hline Norovirus + ETEC & $2(1.8 \%)$ & - & $1(1.3 \%)$ & $3(1.7 \%)$ \\
\hline Norovirus + Shigella spp. & $2(1.8 \%)$ & $2(3.0 \%)$ & $1(1.3 \%)$ & $5(1.9 \%)$ \\
\hline Norovirus + Shigella spp. + ETEC & $1(0.8 \%)$ & - & - & $1(0.4 \%)$ \\
\hline Norovirus + Vibrio cholerae & $2(1.8 \%)$ & $2(3.0 \%)$ & - & $4(1.6 \%)$ \\
\hline Norovirus + rotavirus + Shigella spp. & $1(0.8 \%)$ & - & - & $1(0.4 \%)$ \\
\hline $\begin{array}{l}\text { Norovirus }+ \text { Vibrio cholera }+ \\
\text { Campylobacter spp. }\end{array}$ & $1(0.8 \%)$ & - & - & $1(0.4 \%)$ \\
\hline Vibrio cholerae + Campylobacter spp. & $2(1.8 \%)$ & - & - & $2(0.7 \%)$ \\
\hline Vibrio cholerae + ETEC & $2(1.8 \%)$ & - & - & $2(0.7 \%)$ \\
\hline Salmonella spp. & $1(0.8 \%)$ & - & - & $1(0.4 \%)$ \\
\hline Shigella spp. & $1(0.8 \%)$ & - & $3(3.9 \%)$ & $4(1.6 \%)$ \\
\hline Vibrio cholerae & $6(5.3 \%)$ & $1(1.5 \%)$ & $1(1.3 \%)$ & $8(3.1 \%)$ \\
\hline Aeromonas spp. & $2(1.8 \%)$ & - & - & $2(0.7 \%)$ \\
\hline ETEC & $5(4.4 \%)$ & - & - & $5(1.9 \%)$ \\
\hline
\end{tabular}

collected information on patients' demographic background, medical history, clinical presentation and data from the physical examination. From January to December 2011, 2372 patients from Dhaka, 1295 patients from Matlab and 1676 patients from Mirzapur, all with a history of watery diarrhea, were included in the surveillance. Assuming a 20\% prevalence of noroviruses among hospitalized diarrheal patients with a 95\% confidence level and 5\% confidence interval, the sample size was calculated to be 246. Using SPSS software we randomly selected $5 \%$ of the surveillance stool specimens $(n=257)$ from Dhaka ( $\mathrm{n}=113)$, Matlab $(\mathrm{n}=67)$ and Mirzapur $(\mathrm{n}=77)$ which is sufficient to determine NoV incidence in our study population.

\section{Sample collection and transportation}

A whole stool specimen (at least 3-10 ml or grams) was collected from patients at enrollment in a screw top fecal specimen container (for virus detection) and in Cary-Blair medium (for bacteria detection). Samples were transported in temperature controlled boxes $\left(2-8^{\circ} \mathrm{C}\right)$ to the Virology Laboratory of icddr,b in Dhaka and stored at $-20^{\circ} \mathrm{C}$ until tested.

\section{$R N A$ extraction and $P C R$}

Viral RNA was extracted using the QIAamp ${ }^{\circledR}$ viral RNA mini kit (Qiagen, Hilden, Germany) according to the manufacturer's instructions. Realtime RT-PCR assay with NoV type specific primers and probes to detect NoV GI, GII and GIV targeting ORF1-ORF2 junction region of NoV genome [9] was performed. In brief, a final reaction mixture $(25 \mu \mathrm{l})$ consisting of $5 \mu 1$ RNA, $1 \mu 1$ of Ag-Path enzyme mix, 12.5 $\mu \mathrm{l} \mathrm{Ag-Path} \mathrm{buffer} \mathrm{(Ambion} \mathrm{Inc.} \mathrm{Austin,} \mathrm{USA),} 0.8$ and 0.2 picomol of each primer and probe was prepared. The steps of amplification cycles were: reverse transcription for 30 minutes at $55^{\circ} \mathrm{C}$ followed by denaturation at $95^{\circ} \mathrm{C}$ for 30 seconds, 45 cycles of amplification at $95^{\circ} \mathrm{C}$ for 15 seconds and annealingextension at $60^{\circ} \mathrm{C}$ for 1 minute. The reaction was loaded in to a C1000TM Thermal Cycler (Bio-Rad Laboratories, Hercules, USA), and amplification plots were analysed by Bio-Rad CFX manager software version 1.5.54.0511 (Bio-Rad Laboratories, Hercules, USA). 
Figure 1: Monthly distribution of norovirus positive patients, Bangladesh, 2011.

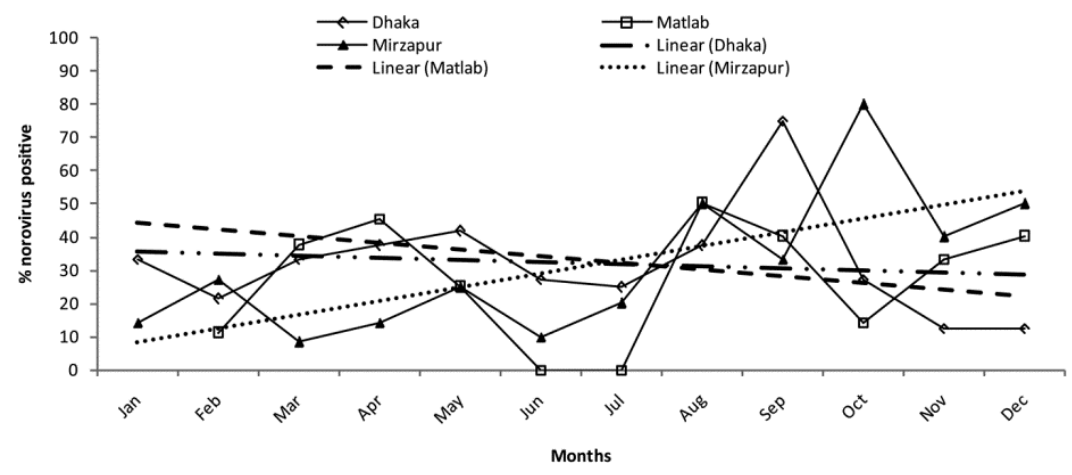

Figure 2: Age distribution of all study patients and norovirus positive patients, Bangladesh, 2011

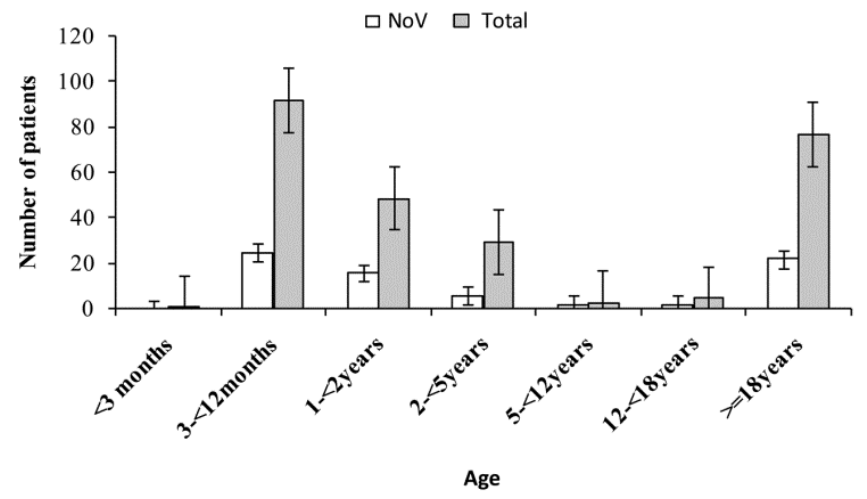

\section{Data analysis}

Differences in proportions of variables related to clinical symptoms were calculated by the chi square test using EPI Info 3.3.2 (Center for Disease Control and Prevention, Atlanta, USA). Statistical significance was considered to be achieved when the $p$ value $\leq 0.05$.

\section{Results}

All study patients were hospitalized with diarrhea defined as loose or watery stools. Of the 257 stool specimens tested, NoV RNA was the most predominant pathogen and was detected in 73 patients $(28.4 \%)$. The detection rate was similar in the three hospitals; Dhaka 34/113 (30\%), Matlab 19/67 (28\%) and Mirzapur 20/77 (26\%). Half of the specimens (37/73) were co-infected with other pathogens including group A rotavirus, Vibrio cholerae, Campylobacter spp, Shigella spp., Salmonella spp., Aeromonas spp., and enterotoxigenic Escherichia coli. (Table 1). The second most common enteric pathogen was rotavirus $70 / 257(27.3 \%)$ and a substantial proportion 108/257 (42\%) of diarrheal patients were negative for any pathogens tested in our study.

NoV was detected throughout the year in all three hospitals except Matlab during June-July (Figure 1).
The regression lines for Dhaka and Matlab were similar and there was no remarkable trend over time; however, the line for Mirzapur showed an increase of $\mathrm{NoV}$ incidence at the end of the year. The virus was detected in both children and adults (ages ranged from 3 months to 81 years, median age 1.3 years) and there was no difference in age distribution between urban and rural areas (Figure 2). Most of the NoV positive patients presented with abdominal cramps 20/36 (55.6\%) and vomiting 25/36 (69.4\%). No blood was identified in their stool. Fever was not common in these patients $2 / 36(6 \%)$ but severe dehydration was identified in $7 / 36(19.4 \%)$ patients.

Among a total of $73 \mathrm{NoV}$ positive samples, NoV GII genogroup, 52/73 (71.2\%) was the most prevalent type followed by GI genogroup, 15/73 (20.5\%) and both of them were co-circulating during the study period. Mixed NoV types (GI + GII) were detected in $5 / 73(7 \%)$ while GIV was identified in one sample.

\section{Discussion}

The aim of the study was to determine the NoV prevalence in hospitalized patients with diarrhea in Bangladesh. The detection rate in this study $(28 \%)$ was much higher than observed in previous studies in 
Bangladesh $[7,8]$ and is comparable to recent published reports from other countries $[9,10]$. Designing of appropriate primer set to detect the full range of NoV types has been difficult due to extensive genomic diversity. New variants can easily remain undetected until their sequences are determined and new primers developed. Previous studies in Bangladesh relied on primers which could detect limited NoV types using conventional PCR which may have been less sensitive compared to real time PCR used in the recent studies. One of the limitations in the detection methods used in this study was that specific primers and probes to human NoV genogroups, GI, GII and rare GIV were used. The possibility of missing animal NoV genogroups, GIII and GV cannot be ruled out.

Unlike rotavirus which is more common among children $<5$ years of age, NoV was detected in both children and adults in our study, a finding that is consistent with several other studies worldwide [11, $12,13]$. Co-infections with virus and bacteria $(17 \%)$ occurred regularly in our study patients. With the limited number of samples analyzed, no differences in clinical symptoms in the patients for multiple or a single enteric pathogen was observed (data not shown) and analysis with more samples is required to explore the role of mixed infections. It was clear from the distribution of different pathogens identified in the study (Table 1) that the etiology of diarrhea is complex and in a substantial proportion of samples, pathogens were not identified. Development of an enteric pathogen testing panel and discovery of novel pathogens using cutting edge technologies such as MassTag PCR, Taqman array or Luminex assays would be required to explore the true burden of pathogens in greater detail $[14,15,16]$.

The Government of Bangladesh are including rotavirus vaccines in the routine vaccination program, which may lead to at least partial control of rotavirus diarrhea in Bangladesh. Since there is no vaccine or treatment against NoV infection, it is possible that $\mathrm{NoV}$ may then become one of the most common causes of childhood diarrhea,. Therefore, continued surveillance of NoV together with other viral and bacterial pathogens in hospitalized gastroenteritis patients as well as in the community will further elucidate the role and burden of different pathogens in diarrheal diseases.

\section{Acknowledgements}

This research work was funded by Swedish International Development Cooperation Agency (Sida). icddr,b acknowledges with gratitude the commitment of Sida to its research efforts.

\section{References}

1. Giaquinto C, Dominiak-Felden G, Van Damme P, Myint TT, Maldonado YA, Spoulou V, Mast TC, Staat MA (2011) Summary of effectiveness and impact of rotavirus vaccination with the oral pentavalent rotavirus vaccine: a systematic review of the experience in industrialized countries. Hum Vaccin 7: 734-748.

2. Parashar UD, Li JF, Cama R, DeZalia M, Monroe SS, Taylor DN, Figueroa D, Gilman RH, Glass RI (2004) Human caliciviruses as a cause of severe gastroenteritis in Peruvian children. J Infect Dis 190: 1088-1092.

3. Patel MM, Widdowson MA, Glass RI, Akazawa K, Vinje J, Parashar UD (2008) Systematic literature review of role of noroviruses in sporadic gastroenteritis. Emerg Infect Dis 14: 1224-1231.

4. Siebenga JJ, Vennema H, Zheng DP, Vinje J, Lee BE, Pang XL, Ho EC, Lim W, Choudekar A, Broor S, Halperin T, Rasool NB, Hewitt J, Greening GE, Jin M, Duan ZJ, Lucero Y, O'Ryan M, Hoehne M, Schreier E, Ratcliff RM,. White PA, Iritani N, Reuter G, Koopmans M (2009) Norovirus illness is a global problem: emergence and spread of norovirus GII.4 variants, 2001-2007. J Infect Dis 200: 802812.

5. Karst SM (2010) Pathogenesis of noroviruses, emerging RNA viruses. Viruses 2: 748-781.

6. Black RE, Greenberg HB, Kapikian AZ, Brown KH, Becker S (1982) Acquisition of serum antibody to Norwalk Virus and rotavirus and relation to diarrhea in a longitudinal study of young children in rural Bangladesh. J Infect Dis 145: 483489.

7. Dey SK, Nguyen TA, Phan TG, Nishio O, Salim AF, Rahman M, Yagyu F, Okitsu S, Ushijima H (2007) Molecular and epidemiological trend of norovirus associated gastroenteritis in Dhaka City, Bangladesh. J Clin Virol 40: 218-223.

8. Rahman M, Hassan Z, Nahar Z, Faruque AS, Van Ranst M, Rahman SR, Azim T (2010) Molecular detection of noroviruses in hospitalized patients in Bangladesh. Eur J Clin Microbiol Infect Dis 29: 937-945.

9. Trujillo AA, McCaustland KA, Zheng DP, Hadley LA, Vaughn G, Adams SM, Ando T, Glass RI, Monroe SS (2006) Use of TaqMan real-time reverse transcription-PCR for rapid detection, quantification, and typing of norovirus. J Clin Microbiol 44: 1405-1412.

10. Liu LJ, Liu W, Liu YX, Xiao HJ, Jia N, Liu G, Tong YG, Cao WC (2010) Identification of norovirus as the top enteric viruses detected in adult cases with acute gastroenteritis. Am J Trop Med Hyg 82: 717-722.

11. Chhabra P, Dhongade RK, Kalrao VR, Bavdekar AR, Chitambar SD (2009) Epidemiological, clinical, and molecular features of norovirus infections in western India. $\mathrm{J}$ Med Virol 81: 922-932.

12. Green KY (1997) The role of human caliciviruses in epidemic gastroenteritis. Arch Virol Suppl 13: 153-165. 
13. Thornton AC, Jennings-Conklin KS, McCormick MI (2004) Noroviruses: agents in outbreaks of acute gastroenteritis. Disaster Manag Response 2: 4-9.

14. Doellinger J, Schroeder K, Witt N, Heunemann C, Nitsche A (2012) Comparison of real-time PCR and MassTag PCR for the multiplex detection of highly pathogenic agents. Mol Cell Probes 26: 177-181.

15. Rachwal PA, Rose HL, Cox V, Lukaszewski RA, Murch AL, Weller SA (2012) The potential of TaqMan Array Cards for detection of multiple biological agents by real-time PCR. PLoS One [Epub 2012 Apr 23].

16. Liu J, Kibiki G, Maro V, Maro A, Kumburu H, Swai N, Taniuchi M, Gratz J, Toney D, Kang G, Houpt E (2011) Multiplex reverse transcription PCR Luminex assay for detection and quantitation of viral agents of gastroenteritis. J Clin Virol 50: 308-313.

\section{Corresponding author}

Mustafizur Rahman,

Virology Laboratory

icddr,b, 68, Shahid Tajuddin Ahmed Sharani

Dhaka-1212, Bangladesh

Phone: +8801712657125, Fax- +8802-8812529

Email: mustafizur@icddrb.org

Conflict of interests: No conflict of interests is declared. 